\title{
ON THE ROLE OF THE IGNEOUS ACTIVITIES IN THE TECTONIC MOVEMENT, WITH SPECIAL REFERENCE TO THE MUROTO PENINSULA IGNEOUS ZONE
}

\author{
Toshiniкo YAJIMA*, Mikio KAJIMA* and Yukio NAGANUMA**
}

(Received September 13, 1976)

\section{Introduction}

A coarse-grained olivine augite gabbroic complex is exposed at Cape Muroto (Murotomisaki), which is located at the south extremity of the Muroto Peninsula, Kochi Prefecture, Japan (Suzuki, 1930; Yoshizawa, 1953, 1954). This gabbroic complex was formed as a horizontally stratified sheet in the Murotohanto Group by fractional crystallization (Yajıma, $1969,1972 \mathrm{a}, \mathrm{b})$ and many dyke swarms and pillow lavas accompanied it. Such a differentiated gabbroic complex is very effective to study the geological structure where the disturbances of clastic rocks are common. The Murotomisaki gabbroic complex, and its derivatives, which were solidified at a certain depth, are now near the sea level, so it is possible to reconstruct the exact geological sections including pillow lavas and gabbroic. complexes. A steep inclination of the formation at the south area of the Muroto Peninsula simplifies this reconstruction.

In recent years, the writers investigated the southern part of the Muroto Peninsula, intending to throw light on the relation between the igneous rock bodies and the geological structures, and found many small gabbroic masses and dykes on the tidal zone along the east coast. They noticed also that there is a remarkable close relation among the igneous activities, the tectonic movement and the di-

* Department of Earth Sciences, Faculty of Education ,Saitama University

** Mamiya Junior High School, Omiya, Saitama Prefecture stribution of the lithofacies. Based on this study a model is proposed below, which explains the variation of lithofacies, and which demonstrates the role of the igneous activities in the tectonic movement.

Acknowledgements The writers wish to express their cordial thanks to Prof. J. Arai of Saitama University for his many useful suggestions and continuous encouragements during the course of this study.

They extend sincere thanks to Dr. Y. Suzuki of the Geological Survey of Japan, for his valuable suggestions to the preparation of this study.

\section{General geology}

The investigated area is located in the southern part of Muroto City, Kochi Prefecture (Fig. 1), where is in the Shimanto terrain of the Outer zone of Southwest Japan. The sedimentary sequences developed in the studied area are the Murotohanto Group after KATTO

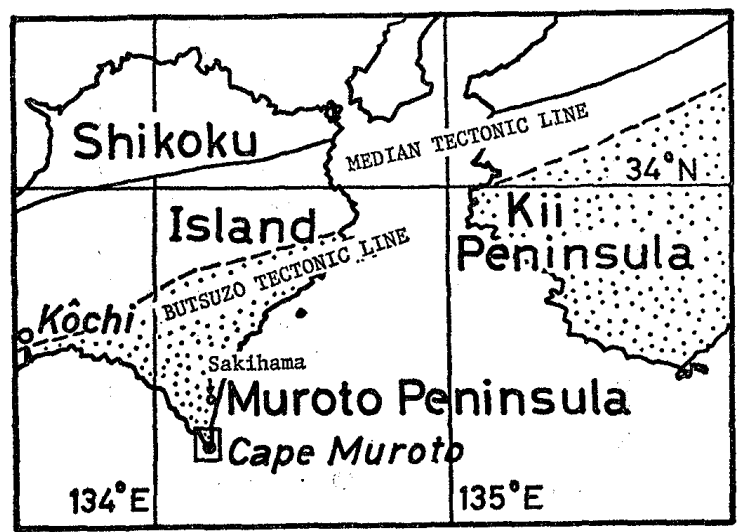

Fig. 1. Locality map. Dotted area : Shimanto terrain. 


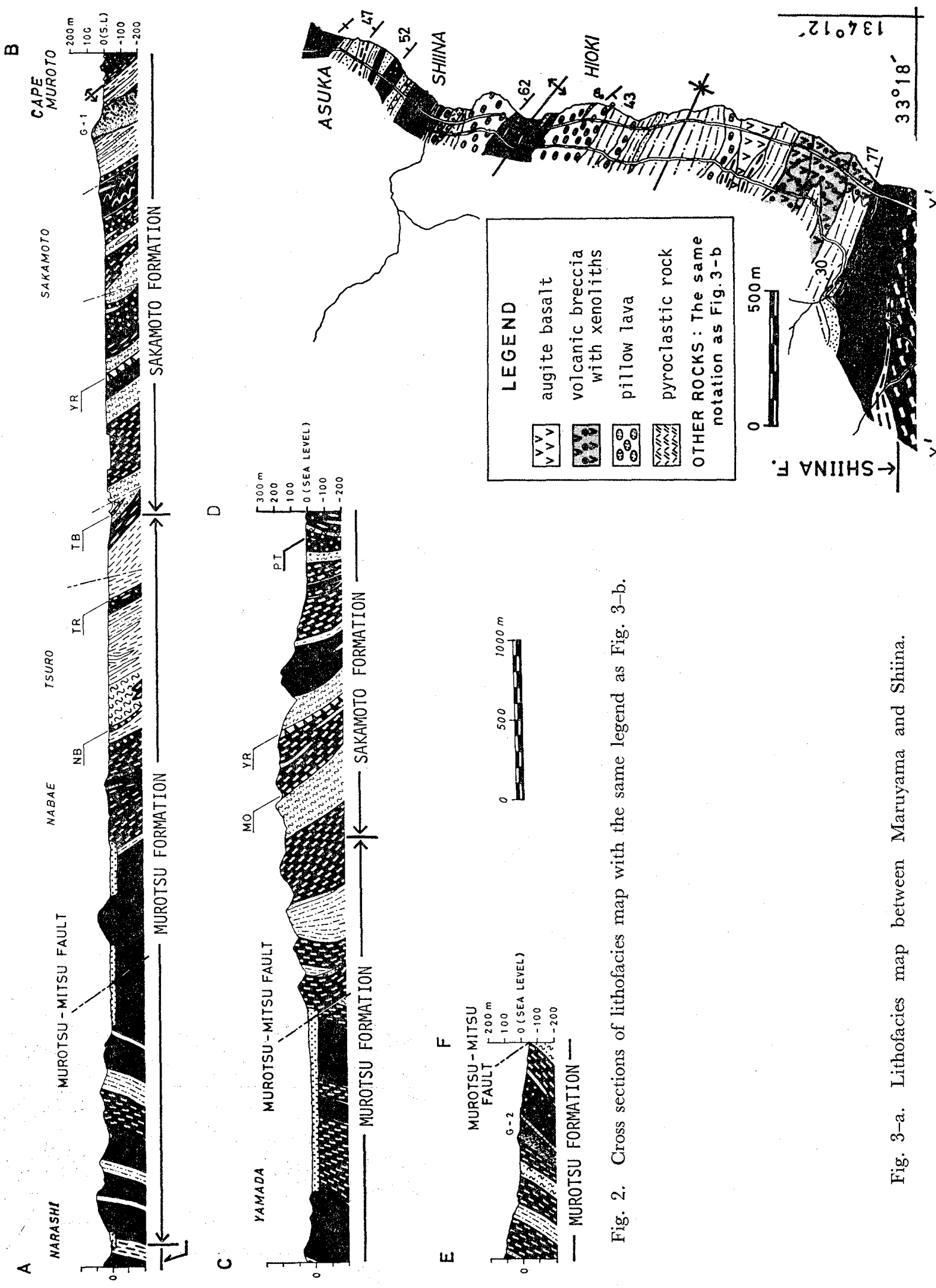




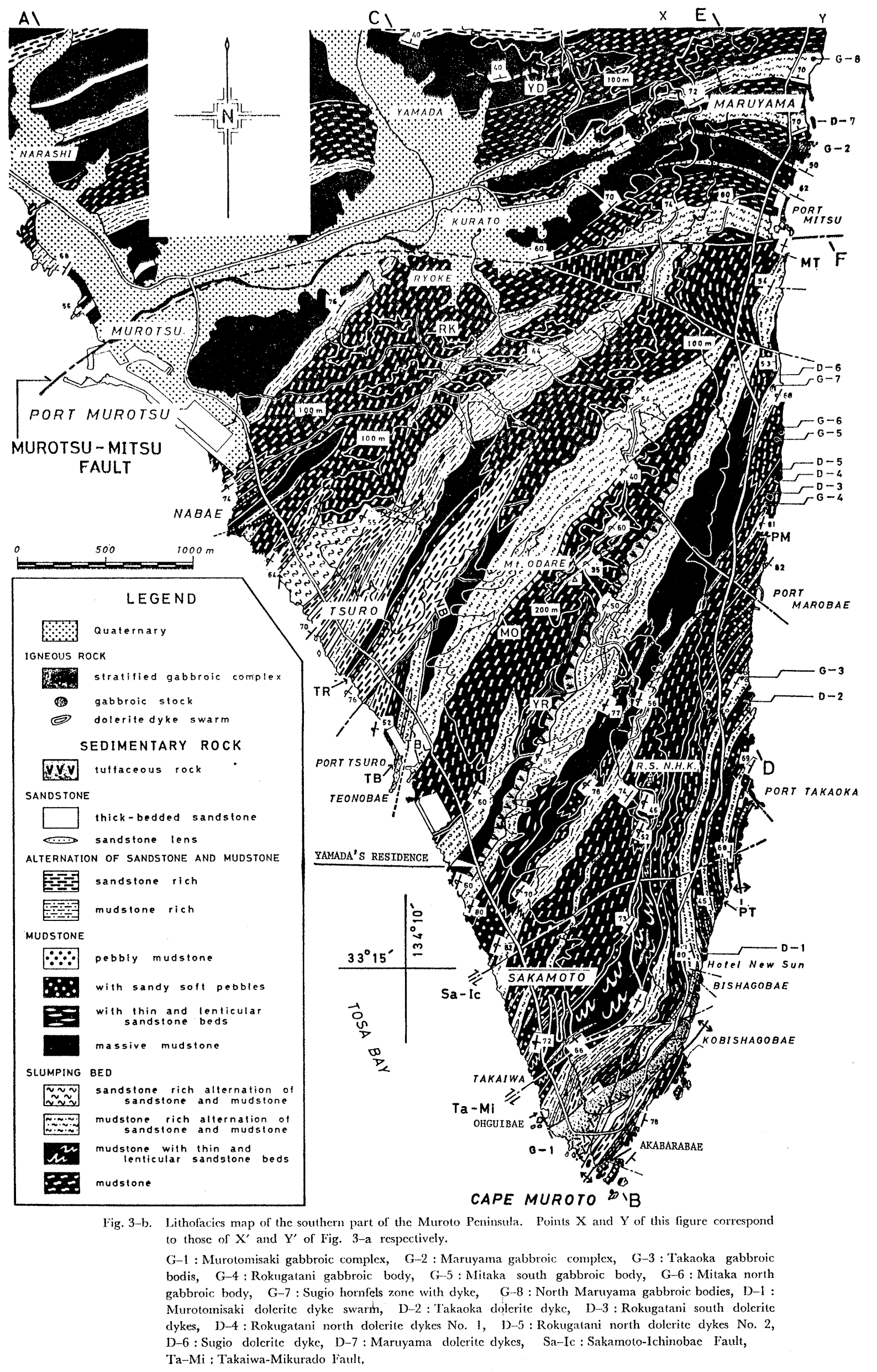




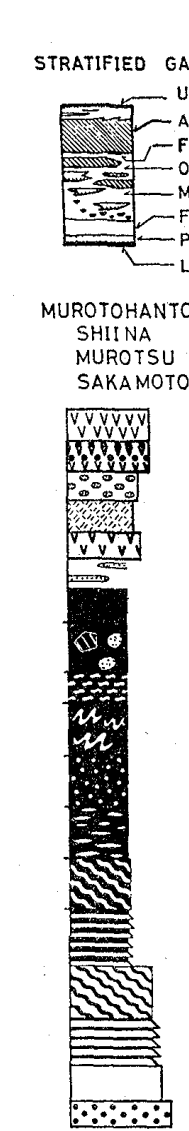

LEGEND

TRATIFIED GABBROIC COMPLEX

Upper chilled margin

Aug. gabbro pegmatite Ferro gabbro

- 0l. aug. gabbro pegmatite

-Medium-grained ol. aug. gabbro Fine-grained ol. aug, gabbro Picrite gabbro

THANTO GROUP

MUROTSU FORMATION

AKAMOTO.FORMATION

Y Augite bosalt

Conglomeratic lava with basal

xenolith

Pillow lava

Pyroclastic rock

Tuffaceous rock

Sandstone lens

Massive mudstone

Mudstone with slump balls

and slump block

Slumping bed of mudstone

Slumping bed of mudstone with thin and lenticular s.s. beds

Mudstone with sandy

soft pebbles

Mudstone with thin and

lenticular sandstone beds

Slumping bed of mudstone rich

alternation of $\mathbf{5 . s}$. and m.s. Mudstone rich alternation of sandstone and mudstone Slumping bed of sandstone rich alternation of 5.5 . and $m$. $s$. andstone rich alternation of

Thick-bedded sandstone

Pebbly mudstone

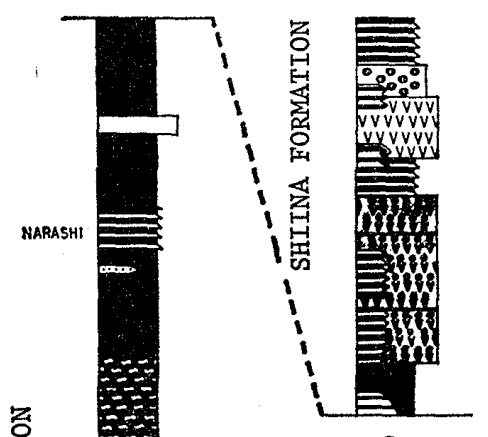

(5)

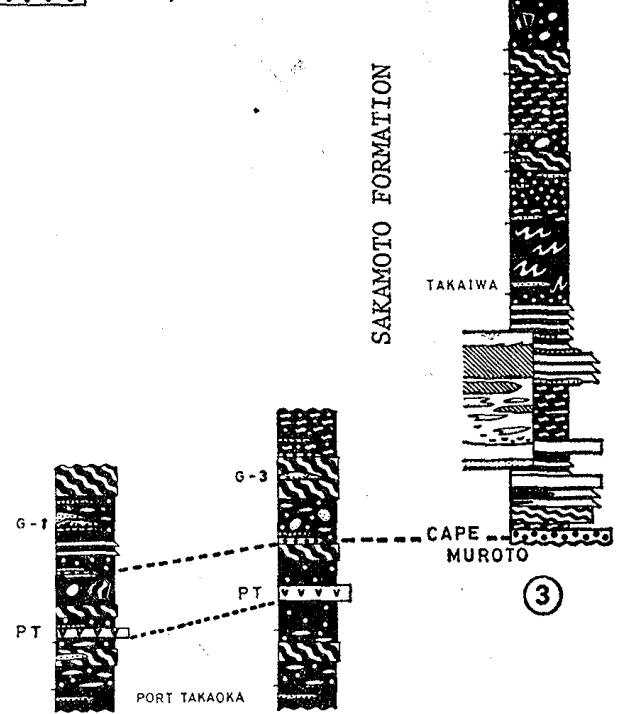

(1)

(2)

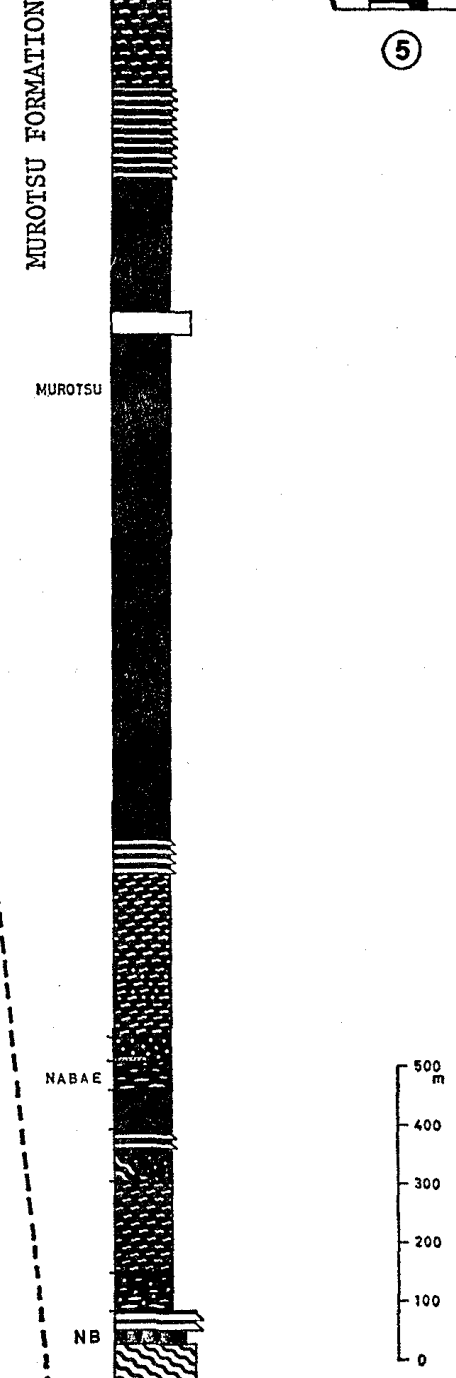

Fig. 4. Columnar sections with the same legend as Fig. 3-b.

(1), (2), (3): Sakamoto Formation, (4) : Murotsu Formation, (5) : Shiina Formation 


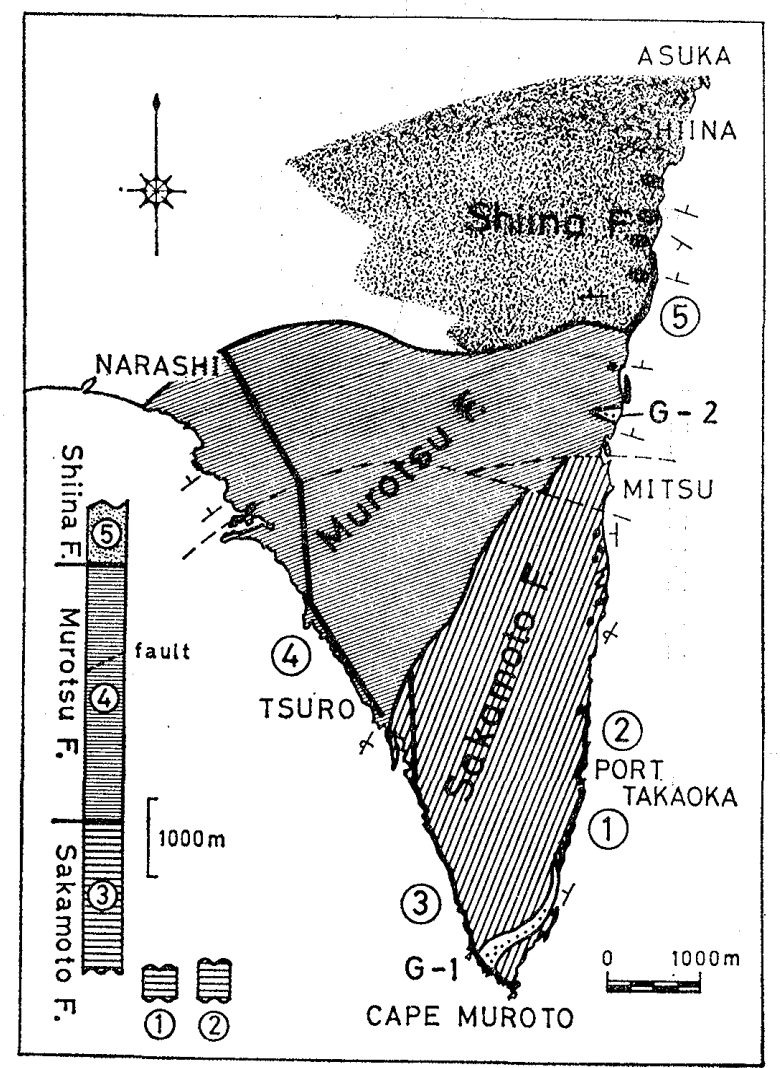

Fig. 5. A schematic geologic map. The routes for the columnar sections are also represented.

(1960), who estimated its age to be Paleogene. The writers divided them into Sakamoto, Murotsu and Shiina Formations in ascending order, which will be described in the next chapter. The lithofacies maps with cross sections and the schematic geologic map are presented in Figs. 2, 3-a, 3-b, 4, and 5.

The Sakamoto Formation consists of the lower sandstone-rich facies with pebbly mudstone at base, and the upper mudstone-rich facies. The Murotsu Formation consists also of the lower sandstone-rich facies without pebbly mudstone at base, and the upper mudstonerich facies. The Shiina Formation consists of the lower sandstone-rich facies intercalated by mudstone-rich facies, and the upper volcanic materials facies of pillow lava and of volcanic breccia along the east coast, which facies is intertongued with the sandstone-rich alternation toward west.

A remarkable feature of the area is that small intrusive and extrusive rocks such as
Murotomisaki, Maruyama gabbroic complexes and Hioki pillow lavas are distributed along the east coast in north-south direction. These igneous rocks, including intrusives and extrusives, are the products of olivine tholeiite magma (Yoder \& Tilley, 1962) through the process of fractional crystallization (YAJIMA, 1972b). And there are close correspondences between the intrusives and the extrusives as it will be discussed later.

\section{Stratigraphy}

Until now, the Murotohanto Group in the studied area is named Muroto Formation (Suzuki, 1930; KatTo, 1969), however, that group in this area is subdivided into three formations, Sakamoto, Murotsu and Shiina Formations, in ascending order.

\section{Sakamoto Formation}

Type Succession The west coast between the south extremity of Cape Muroto and north of Port Tsuro, Kochi Prefecture (Line (3) in Fig. 5).

Distribution The formation is distributed in the area southeast of a line connecting north of Port Tsuro and Port Mitsu on the east coast (Fig. 5).

Thickness About $2,000 \mathrm{~m}$ on the west coast, the type locality, and about $1,100 \mathrm{~m}$ on the east coast.

Stratigraphic Relation Lower limit of this formation can not be observed. The pebbly mudstone at Port Takaoka is the lowermost clastics distributed on land.

Lithofacies In general, the coarsegrained facies thins out northeastward in this Sakamoto Formation. The coarse-grained facies thins out or disappears at the summit of the wavy structure.

Thick-bedded sandstone Comparatively thick-bedded sandstone is developed at above and below the gabbroic intrusive body $(\mathrm{G}-1)$ behind Hotel New. Sun, and at the extremity of the Cape (Fig. 3-b). Mudstone beds are not intercalated in this sandstone, except a few very thin beds, which attain to several centimeters thick in general. Weak slumping structure is noticed sometimes in these thick sandstone beds. Sandstone beds 
are teared off very often, the length of which is commonly 2 to $8 \mathrm{~m}$ although some sandstone beds reach $10 \mathrm{~m}$ thick, and some tens of meters in length, some tens of centimeters thick. These sandstones are pale brown in colour in most cases, but some one looks pale grey or grey. Sandstone is generally medium in grain size, but is not seldom fine.

\section{Sandstone-rich alternation of sandstone} and mudstone Sandstone-rich alternation is developed in the lower position of this formation, and is exposed at the extremity of Cape Muroto, at the south and the north adjacent horizons of the Murotomisaki gabbroic complex $(\mathrm{G}-1)$ at Ohguibae.

Sandstone unit of this alternation is about $30 \mathrm{~cm}$ thick on an average. Mudstone unit is about $5 \mathrm{~cm}$ thick. Sandstone is brown or greyish brown in colour and fine-grained with ill sorting. Mudstone is black, with many small fractures. In most cases, sandstone unit lies on the eroded surface of lower mudstone unit and flute or groove casts are observed on the bottom surface of some sandstone units. Linguoidal ripples are developed on the top surface of the sandstone, at the upper part or through the whole inner part of which are expressed by the ripple cross-lamination.

Mudstone-rich alternation of sandstone and mudstone Mudstone-rich alternation is developed in the upper part of the Sakamoto Formation, e.g. at $70 \mathrm{~m}$ below the tuffaceous rock in front of "Mr. Yamada's Residence" (YR, see below) and at Ohguibae, south of Takaiwa. As a whole, sandstone unit is 3 to $5 \mathrm{~cm}$ thick, while mudstone unit is 8 to $10 \mathrm{~cm}$. Very fine-grained lower sandstone transits gradually into the upper mudstone in a single bed. The boundary between the neighbouring beds is sharp, with no conspicuous eroded surface on the top of the mudstone. Boudinage structures are observed frequently in the sandstone beds.

Pebbly mudstone (Mudstone with pebbles, cobbles and boulders) Pebbly mudstones, 5 to $20 \mathrm{~m}$ thick, are well observed at the extremity of Cape Muroto, and at the seashore behind Hotel New Sun. The pebbles in these mudstones show well rounded oval shape. Two kinds of pebbles are distinguished, na- mely, those derived from the pre-Tertiary formations and from the Shimanto Supergroup. Rounded or subrounded pebbles of chert, sandstone, granitic rock, calcareous rock, and orthoquartzite belong to the former, while angular pebbles of sandstone, and alternation of sandstone and mudstone, belong to the latter.

A good example of mudstone accompanying reeroded sandstone pebbles of the Shimanto Supergroup is exposed in the surrounding area of a small gabbroic intrusive rock $(\mathrm{G}-3)$ near Port Marobae. There are two kinds of pebbles, that is, rounded and angular ones. Size of larger pebbles attains to about $50 \mathrm{~cm}$ in diameter. Pebbles of $10 \mathrm{~cm}$ in average diameter are common. Thin intercalated sandstone beds less than $5 \mathrm{~cm}$ thick and/or slump blocks are observed in this type of mudstone.

Mudstone with thin and lenticular sandstone beds Mudstone with thin and lenticular sandstone beds is one of the major constituents of this formation and well observed at the seashore south of Port Talsaoka. Parallel laminations are common in the sandstone beds. These sandstone beds thin out within a distance of several meters.

Massive mudstone Mudstone is a black massive silty rock and very brittle on the weathered surface. Concentrations of fine pyrite are not seldom.

\section{Tuffaceous rocks}

PT (Port Takaoka tuffaceous beds, new nomination) Conspicuous tuffaceous beds of the lowermost horizon in the Sakamoto Formation can be observed at the place between Port Marobae and Port Takaoka, and also at the place between Hotel New Sun and Port Takaoka, of which the former is designated as the type locality. The beds at the type locality consist of five alternative units of green tuff and tuffaceous fine-grained sandstone, the thickest unit attaining to $5.1 \mathrm{~m}$. The total thickness measures $30.4 \mathrm{~m}$ at the type locality. The beds at the latter place consist of three units of similar constituents with a total thickness of $15.3 \mathrm{~m}$. The tuffaceous beds at these two points are correlative with each other.

YR (Tuffaceous beds in front of $\mathrm{Mr}$. Yamada's Residence, Katro, 1969) Tuffaceous beds are observed at the seashore in 
front of "Mr. Yamada's Residence". They are divided into three units, being developed at a horizon $550 \mathrm{~m}$ above PT. The lower unit consists of some tens of alternative subunits of greenish grey shale and red shale. Each bed is $5 \mathrm{~cm}$ thick, and total thickness attains to $14 \mathrm{~m}$. The middle unit is composed of three beds of comparatively thick alternative greenish grey shale and two beds of red shale. The thickness of this unit attains to $49.1 \mathrm{~m}$. The upper unit consists of mudstone intercalated by the various kind of green tuffaceous rocks from 30 to $5 \mathrm{~cm}$ thick. The thickness of the upper unit attains to $46 \mathrm{~m}$. The tuffaceous beds YR can be continuously traced northeastward from the western seashore to a cutting on "the Muroto Skyline", but they thin out further northeastward and only tuffaceous sandstone is observed behind Sugio Shrine.

MO (Mt. Odare tuffaceous beds, new nomination) Greenish sandy tuffaceous beds are observed at a cutting on "the Muroto Skyline", NNE of Mt. Odare, the type locality. Total thickness attains to about $8 \mathrm{~m}$.

TB (Teonobae tuffaceous beds, new nomination) This bed of $12 \mathrm{~m}$ thick is exposed at Teonobae of Tsuro, the type locality. This bed is composed of alternation of green muddy beds and green cherty beds. Thickness of each unit attains to 5 to $15 \mathrm{~cm}$. Slumping structures are very common in these beds.

Other tuffaceous beds At a point 20 $m$ north of Takaiwa, exposed are three small lenses of dark greenish grey shale $(5$ to $10 \mathrm{~cm}$ thick), which are accompanied by sporadically intercalated tuffaceous sandstone beds ( 5 to 15 $\mathrm{cm}$ thick). It attains to $35 \mathrm{~cm}$, in maximum thickness and $8 \mathrm{~m}$ in length. Partial slump fold is observed. Total thickness of these tuffaceous beds attains to about $5 \mathrm{~m}$.

\section{Murotsu Formation}

(new nomination)

Type Succession The west coast of Muroto Peninsula between a point, north of Port Tsuro and Narashi, Kochi Prefecture (Line (4) in Fig. 5).

Distribution The formation is distributed in the nearly triangular area defined by Narashi, north of Maruyama, Port Mitsu and south of Port Tsuro (Fig. 5). The MurotsuMitsu Fault traverses this Murotsu Formation, but the lower half part of the Murotsu Formation is exposed on the south side of this fault, while the upper half part of the Murotsu Formation is exposed on the north side of that fault.

Thickness About $3,500 \mathrm{~m}$ on the west coast. The whole succession is distributed on this west route.

Stratigraphic Relation This formation lies conformably on the Sakamoto Formation.

Lithofacies The coarse-grained facies is predominant in the lower half part of the Murotsu Formation at the west coast. This facies changes into the muddy facies northeastward. This tendency is very similar to that of the Sakamoto Formation. The muddy facies is predominant in the upper part of this formation.

Thick-bedded sandstone Thick-bedded sandstone beds are often found in the lower part of the Murotsu Formation. Two sandstone beds observed at Tsuro are 30.8 and $18 \mathrm{~m}$ thick respectively from south to north. They are massive fine-grained and pinkish grey or pale brown in colour. Gradings are weakly developed and parallel or cross lamination is not so clear. Slumping structures are found in the thickest part of the beds, where thin mudstone bed of 0.1 to $0.5 \mathrm{~cm}$ thick are intercalated. On the east coast, thick-bedded sandstone beds are distributed at $100 \mathrm{~m}$ south of the Maruyama gabbroic complex (G-2) and at the south contact of the same complex (Fig. $3-b)$. The former is white brown, mediumgrained and massive sandstone. The latter is fine-grained and affected by contact metamorphism.

Sandstone-rich alternation of sandstone and mudstone Sandstone-rich alternation of sandstone and mudstone occurs in the lower part of the Murotsu Formation at Tsuro. Slumping structures are very common. Typical examples are observed at the seashore behind the Fishery High School of Nabae. On an average, sandstone unit of this alternation is about $25 \mathrm{~cm}$ thick. Mudstone unit is about $5 \mathrm{~cm}$ thick. Sandstone unit more 
than $2 \mathrm{~m}$ thick is rarely observed. Sandstone is brown or greyish brown in colour and finegrained with ill sorting. Mudstone is black in colour, with many small fractures. In most cases, sandstone unit lies on the eroded surface of mudstone unit, and flute casts and/or groove casts are often found on the bottom surface of sandstone unit. Linguoidal ripples are developed on the top surface of the sandstone unit at the upper part or through the whole inner part of which are expressed by the ripple cross-lamination, just the same as in the Sakamoto Formation.

Mudstone-rich alternation of sandstone and mudstone Mudstone-rich alternations are well observed at Tsuro. Sandstone unit of the alternation is 3 to $5 \mathrm{~cm}$ thick, fine-grained and brown or dark green in colour, and gradings are well developed, while mudstone unit is 5 to $15 \mathrm{~cm}$ thick and black in colour. Gradings are also clearly observed at the part between the lower sandstone unit and the upper mudstone unit. The upper surface of mudstone unit is eroded out by the overlying sandstone unit without exception. Trace fossils are very common on the lower surface of the sandstone unit.

Mudstone Mudstones are massive and black in colour and almost all of them show slumping structures. A good exposure is observed at the place north of the Maruyama gabbroic complex $(\mathrm{G}-2)$. There are three horizons of mudstone beds of 30,55 and 135 $m$ thick from south to north (Fig. 3-b).

Rounded pebbles of mudstone and/or pale brown sandstone, which attain to 10 to 40 $\mathrm{cm}$ in diameter, are occasionally enclosed in mudstone bed. Lenses of alternated sandstone and mudstone are intercalated in the slumping mudstone. Some of them attain to some tens of centimeters in thickness.

In the Murotsu Formation distributed to the north of Nabae, muddy clastics are predominant. Black or pale brown mudstone in this area is very brittle and thin laminated. Pebbles are rarely found in this mudstone.

\section{Tuffaceous rocks}

TR (Tsuro tuffaceous beds, new nomination) Green coloured fine-grained sandy tuff beds of $17 \mathrm{~m}$ thick are observed at the seashore in front of the radar of the Fishery High School at Port Tsuro, the type locality.

NB (Nabae tuffaceous beds, new nomination) Green tuffaceous fine-grained sandy beds with red mudstone are found at a horizon $447 \mathrm{~m}$ above the Tsuro tuffaceous beds (TR). The tuffaceous beds, with a total thickness of $24 \mathrm{~m}$. Slumping structures are observed in these beds.

RK (Ryoke tuffaceous beds, new nomination) A thin white or pale greenish sandy tuffaceous lens of $0.8 \mathrm{~m}$ thick is exposed at Ryoke, the type locality, in the northern part of the distributed area of the Murotsu Formation. It consists of very thin small lenses of several centimeters thick with length 2 to $3 \mathrm{~m}$.

YD (Yamada tuffaceous beds, new nomination) White or pale brown tuffaceous beds intercalated between three beds of medium-grained sandstone of $30 \mathrm{~cm}$ thick are observed in an orange orchard of Yamada, type locality, in the north part of the distributed area of the Murotsu Formation. Total thickness attains to about $15 \mathrm{~m}$. There is exposed a green tuffaceous bed of $1.9 \mathrm{~m}$ thick with tuffaceous sandstone at a horizon $69 \mathrm{~m}$ above TR. Many weak slumping structures are found in tuffaceous rock suggesting the fluidal movement of volcanic materials before consolidation of mud. The extension of YD could hardly be recognized because of partial disturbance.

Small lenses of dark greenish sandy tuffaceous rocks of 1 to $10 \mathrm{~cm}$ thick and 0.3 to $1 \mathrm{~m}$ long are observed in the mudstone, north of Maruyama, on the east coast.

\section{Shiina Formation}

(new nomination)

Type Succession Between a point $1 \mathrm{~km}$ north of Maruyama and Shiina along the east coast, Kochi Prefecture (Line (5) in Fig. 5 and its northern extension).

Distribution The formation is distributed round Mt. Shijuji, River Murotsu and their surrounding areas. It is exposed also in the northern area (Fig. 5).

Thickness About $680 \mathrm{~m}$ on the east coast.

Stratigraphic Relation The formation lies conformably on the Murotsu Formation. 
The upper limit was not yet ascertained in this study.

Lithoracies The formation is characterized by comparatively thick massive sandstones and also by thick beds of volcanic materials.

Thick-bedded sandstone The sandstone in the lower horizon of the Shiina Formation, at $1 \mathrm{~km}$ north of Maruyama, is pale brown in colour without lamination, but gradings can be well recognized. Thin pale brownish sandstone beds are observed below the pillow lava at Hioki (Fig. 3-a).

Alternation of sandstone and mudstone The alternation mainly belong to mudstonerich alternation. Sandstone unit of this alternation is about 2 to $5 \mathrm{~cm}$ thick on an average, and brown in colour. Mudstone unit is about $10 \mathrm{~cm}$ thick and pale brown in colour.

Mudstone Rounded pebbles of sandstone or mudstone, 3 to $8 \mathrm{~cm}$ in diameter, are rarely found in it. The mudstone bed is well observed at $300 \mathrm{~m}$ south of Shiina (Fig. 3-a).

Volcanic breccia with xenoliths Volcanic breccia of basalt, which includes xenoliths of gneissose rocks and schist, is distributed in the south of Hioki (Fig. 3-a). The size of breccia is $5 \mathrm{~cm}$ or around on an average and some attain to 30 to $40 \mathrm{~cm}$. Xenolithic fragments, 0.5 to $5 \mathrm{~cm}$ in diameter, are rather brittle. Phenocrysts of plagioclase are characteristic of the basaltic breccias.

Augite basalt The augite basalt lava is exposed surrounded by volcanic breccia (Fig. 3-a). Thickness of this augite basalt bed attains to more than $50 \mathrm{~m}$. Phenocrysts of augite and plagioclase are often found in this basalt. Groundmass and phenocryst are very fresh under microscope without any alteration product.

Pillow lava Outline of pillows is well preserved (Fig. 3-a). The longitudinal diameter of a pillow attains to 1 to $2 \mathrm{~m}$. This pillow lava is characterized by the presence of plagioclase phenocrysts. The groundmass of this pillow lava is albitized completely.

Pyroclastic rock Pyroclastic rock of basaltic composition, with volcanic fragments of $0.5 \sim 5.0 \mathrm{~cm}$ in diameter with abundant fine-grained matrix, is distributed at south of

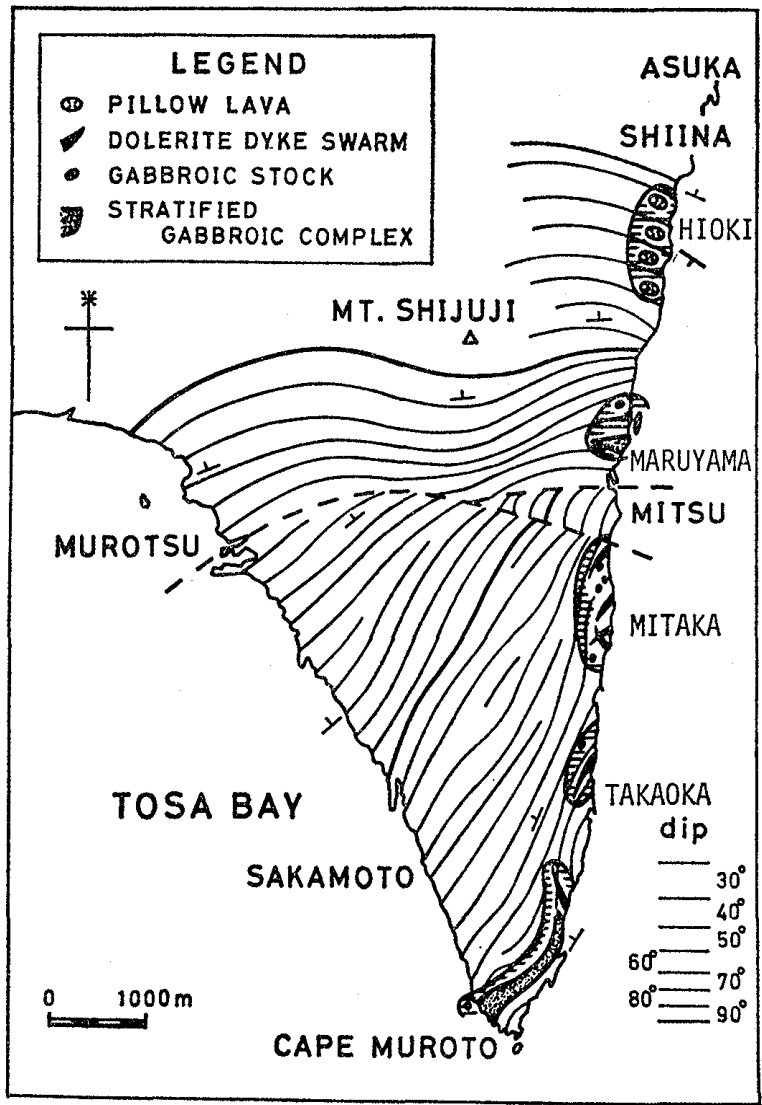

Fig. 6. Strike-line map. The areas of concentrated igneous extrusives and intrusives are also illustrated by the enclosed figures.

Shiina (Fig. 3-a). Thickness of this pyroclastic rock bed attains to $20 \mathrm{~m}$. Diversity of colour from reddish brown to green or to black is outstanding to this pyroclastic rock.

\section{Geological structure}

A NW-dipping steep monoclinal structure with a general trend of NE-SW direction is the principal structure in the studied area. However, a northward-dipping nose structure developed near Mitsu suggests that the area represents the west wing of this nose structure. As a minor structure, weakly developed wavy structures are observed on the east coast.

\section{The principal structure of the first order}

For the principal geological structure, the studied area can be divided into two subareas, one is that of the Sakamoto and of the lower Murotsu Formations, another is that of the upper Murotsu and of the Shiina Formations. A strike-line map of this area represents these 
principal structures (Fig. 6).

a) At the subarea consisting of the Sakamoto and of the lower Murotsu Formations, a steep monoclinal structure is characteristic although reverse dippings are not scarcely observed. Besides, an anticlinal axis is developed from the south extremity of Cape Muroto through Akabarabae and the east coast to the east margin of Port Takaoka. Judging from this anticlinal structure, this subarea is concluded to be a west wing of a large anticlinal structure along the east coast. The anticlinal axis extends more than $6 \mathrm{~km}$.

b) At the subarea consisting of the upper Murotsu and of the Shiina Formations, the general strike indicates $\mathrm{E}-\mathrm{W}$ direction. The nose structure observed at Mitsu is deduced to be the extension of the anticlinal structure at the southern subarea.

c) There is a Murotsu-Mitsu fault between the two above mentioned subareas as it will be described later. The strikes of the Murotsu Formation on the both sides of this fault at the western part give the same value, suggesting the continuity of the lower Murotsu Formation to the upper Murotsu Formation, while the strikes of the upper Murotsu Formation are discordant to those of the lower Murotsu Formation on the east coast.

\section{The minor structure of the second order}

The principal strike represents almost $\mathrm{NE}_{-}$ SW direction on the west coast, while it varies its direction as $\mathrm{S}$ alphabetical character in an area between Bishagobae and Port Takaoka (Fig. 3-b). At Port Marobae and its north adjacent area, similar wavy variation in distribution pattern of strike is observed on a small scale. This fact means that there are wavy structures of small scale in the east coast, wave length of which attains to 2,000 $\mathrm{m}$. Corresponding to this variation of strike, dip represents repetition of normal dip and reverse dip of small scale, however, the general inclination of dip in this area is reversely south direction as a whole. The same wavy structure is observed at west of Maruyama and also at the surrounding area of Murotomisaki gabbroic complex (G-1).

\section{Faults}

The major fault system in this district is the Murotsu-Mitsu fault. This fault, extending along a line between Murotsu and Port Mitsu, is the largest fault in the studied area, traversing the Murotsu Formation (Fig. 6). The displacement by this fault is not yet finally determined, but it is estimated to be not so much on the following evidences. First, this fault traverses the Sakamoto Formation at near Port Mitsu, but the displacement by this fault is not so much in the eastern part as it is represented on Figs. 5, 6. Second, there is not so much difference in the direction of strike of both sides of the fault. Third, the lithofacies is almost continuous to each other at the both sides of this fault.

There are two principal fault systems with NE-SW direction (group-a), and NW-SE direction (group-b). Right wrench faults are predominant in the latter. Strike and dip of the Takaiwa-Mikurado fault (Fig. 3-b) are $\mathrm{N}$ $72^{\circ} \mathrm{E}$, and $56^{\circ} \mathrm{S}$ respectively, whereas those of the Sakamoto-Ichinobae fault (Fig. 3-b) are $\mathrm{N} 62^{\circ} \mathrm{E}$, and south dip. These two faults are almost pararell to each other, and right wrench fault with displacement of 5 to $30 \mathrm{~m}$ and belong to the group-a. The fault with strike of $\mathrm{N} 55^{\circ}$ $\mathrm{W}$ at Bishagobae, and the fault with strike of $\mathrm{N} 30^{\circ} \mathrm{W}$ at Port Takaoka belong to the groupb. The faults of group a are estimated to belong to the earlier stage of faulting in this area.

\section{Discussions and conclusions}

There is a close relation between the tectonic movements and the igneous activities. The igneous activities are controlled principally by the tectonic movements, however, at the same time, the tectonic movements are regulated by the igneous activities at depth. Based on the observation at the studied area, this relation will be discussed in the following sections.

\section{Muroto peninsula igneous zone}

The igneous rocks of small scale are concentrated on a narrow zone, which locates on the east coast of the Muroto Peninsula (Figs. 3-a, 3-b, 6 and 7). They are Murotomisaki gabbroic complex (G-1), Murotomisaki doler- 


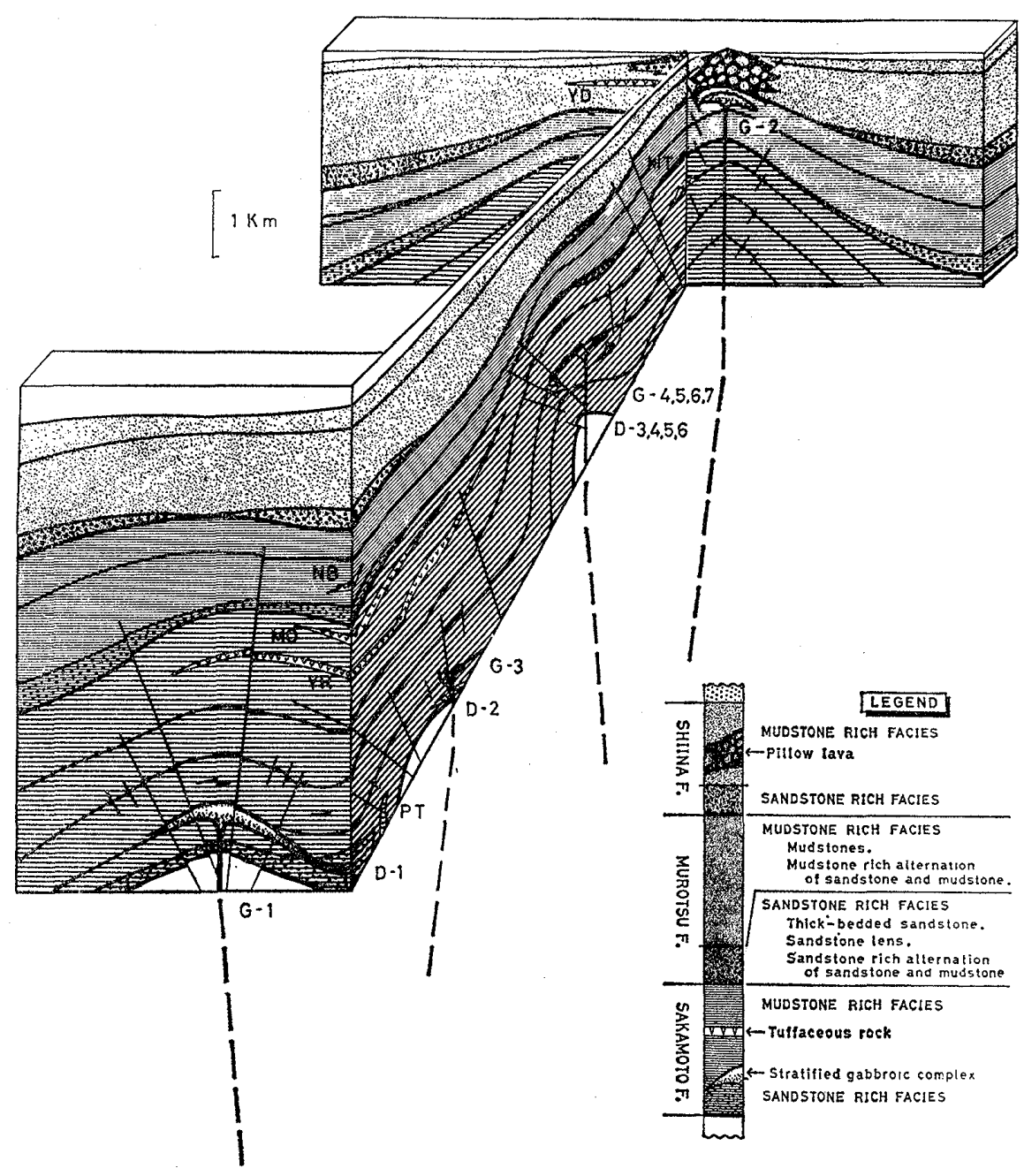

Fig. 7. A model representing the relation between the igneous activities and the tectonic movements. Almost real scale for the clastics and partly exaggerated for the igneous rocks.

ite dyke swarm (D-1), Takaoka dolerite dyke (D-2), Takaoka gabbroic bodies (G-3), Rokugatani gabbroic body (G-4), Rokugatani south dolerite dykes (D-3), Rokugatani north dolerite dykes No. 1 (D-4), Rokugatani north dolerite dykes No. 2 (D-5), Mitaka south gabbroic bodies (G-5), Mitaka north gabbroic body (G-6), Sugio hornfels zone with dyke $(\mathrm{G}-7)$, the Sugio dolerite dyke (D-6), Maruyama gabbroic complex (G-2), the Maruyama dolerite dykes (D-7) and north Maruyama gabbroic body (G-8) from south to north. Principal geological features of these intrusive rocks are summarized on Table 1 . These intrusive rocks are very small and not so much amount, however, almost all these rocks are distributed along the tidal zone of the east coast, and they thin out westward on land. Hence, the intruded magma is estimated to have been supplied from east side, and much more igneous rocks might be expected to be found in the sea.

In this paper, the word "gabbro" is used for the coarse-grained basic igneous rocks, while "dolerite" for the fine-grained basic rock. The gabbroic bodies in this area are characterized by the presence of the structures of igneous sedimentation of the rock-forming minerals under the gravity field. So, it is very effective for the determination of the direction of the intrusion of magma to study that structure. Such structure formed by the igneous sedi- 
Table 1. Geological features of the intrusive rocks.

\begin{tabular}{|c|c|c|c|c|c|c|}
\hline No. & Name & Form & Size & Number & $\begin{array}{l}\text { Direction of } \\
\text { the intrusion }\end{array}$ & Ṙock species \\
\hline$\overline{\mathrm{G}-1}$ & $\begin{array}{l}\text { Murotomisakj } \\
\text { gabbroic complex }\end{array}$ & $\begin{array}{l}\text { sheet } \\
\text { lopolith }\end{array}$ & $230 \mathrm{~m} \times 1800 \mathrm{~m}$ & T & SSW-NNE & $\begin{array}{l}\text { chill.-m.-dol.,picrite g.,01.-aug. -g., } \\
\text { aug.-g.;aug.-g.-pegmatite, ferro-gabbro. }\end{array}$ \\
\hline$\overline{G-2}$ & $\begin{array}{l}\text { Maruyama } \\
\text { gabbroic complex }\end{array}$ & $\begin{array}{l}\text { sheet } \\
\text { phacolith }\end{array}$ & $130 \mathrm{~m} \times 230 \mathrm{~m}$ & 1 & $E-W$ & $\begin{array}{l}\text { chill.-m.-dol,,picrite g.,ol,-aug.-g., } \\
\text { aug.-g.,aug.-g.-pegmatite }\end{array}$ \\
\hline$\overline{\mathrm{G}-3}$ & $\begin{array}{l}\text { Takaoka } \\
\text { gabbroic bodies }\end{array}$ & $\begin{array}{l}\text { ellipsoidal } \\
\text { pipe }\end{array}$ & $\begin{array}{l}3 \mathrm{~m} \times 5 \mathrm{~m} \\
3 \mathrm{~m} \times 10 \mathrm{~m}\end{array}$ & 2 & vertical & chilled marginal dolerite, aug.-gabbro \\
\hline$G-4$ & $\begin{array}{l}\text { Rokugatani } \\
\text { gabbroic body }\end{array}$ & uncertain & $50 \mathrm{~m} ? \times 50 \mathrm{~m} ?$ & $T$ & vertical? & ol.-aug.-gabbro,aug.-gabbro \\
\hline$\overline{G-5}$ & $\begin{array}{l}\text { Mitaka south } \\
\text { gabbroic bodies }\end{array}$ & $\begin{array}{l}\text { irregular } \\
\text { pipe }\end{array}$ & $\begin{array}{r}13 \mathrm{~m} \times 3 \mathrm{~m} \\
8 \mathrm{~m} \times 6 \mathrm{~m} \\
\end{array}$ & 2 & vertical & $\begin{array}{l}\text { chilled marginal dolerite, aug.-gabbro } \\
\text { segregation vein }\end{array}$ \\
\hline$\overline{\mathrm{G}-6}$ & $\begin{array}{l}\text { Mitaka north } \\
\text { gabbroic body }\end{array}$ & $\begin{array}{l}\text { irregular } \\
\text { pipe }\end{array}$ & $10 \mathrm{~m} \times 8 \mathrm{~m}$ & $T$ & vertical & $\begin{array}{l}\text { ol.-aug.-gabbro, aug - gabbro } \\
\text { pegmatitic segregation vein }\end{array}$ \\
\hline$\overline{\mathrm{G}-7}$ & $\begin{array}{l}\text { Sugio hornfels } \\
\text { zone with dyke }\end{array}$ & unknown & unknown & $T$ & unknown & unknown \\
\hline$\overline{\mathrm{G}-8}$ & $\begin{array}{l}\text { North Maruyama } \\
\text { gabbroic body }\end{array}$ & $\begin{array}{l}\text { irregular } \\
\text { pipe }\end{array}$ & $5 \mathrm{~m} \times 10 \mathrm{~m}$ & 7 & vertical & undetermined \\
\hline$\overline{D-7}$ & $\begin{array}{l}\text { Murotomisaki } \\
\text { dolerite dyke sw }\end{array}$ & $\begin{array}{ll}\text { dyke } & w \\
& \text { arm }\end{array}$ & $\begin{array}{l}\text { width:max. } 1.0 \mathrm{~m} \\
\text { length: } 10 \mathrm{~m} \rightarrow 40 \mathrm{~m}\end{array}$ & 50 & SSE-NNW & dolerite \\
\hline$\overline{D-2}$ & $\begin{array}{l}\text { Takaoka } \\
\text { dolerite dyke }\end{array}$ & dyke & $0.6 \mathrm{~m} \times 3 \mathrm{~m}$ & $T$ & SW-NE & dolerite \\
\hline$\overline{D-3}$ & $\begin{array}{l}\text { Rokugatani south } \\
\text { dolerite dykes }\end{array}$ & dyke & $0.6 \mathrm{~m} \times 5 \mathrm{~m}$ & 2 & $\begin{array}{r}\mathrm{S} 30-40^{\circ} \mathrm{E}- \\
\mathrm{N} 40-30^{\circ} \mathrm{W} \\
\end{array}$ & dolerite \\
\hline$\overline{D-4}$ & $\begin{array}{l}\text { Rokugatani north } \\
\text { dol.dykes No.l }\end{array}$ & dyke & $0.6 \mathrm{~m} \times ?$ & 2 & $\begin{array}{r}\mathrm{S} 30-40^{\circ} \mathrm{E}- \\
\mathrm{N} 40-30^{\circ} \mathrm{W}\end{array}$ & dolerite (coarse-grained) \\
\hline$\overline{\mathrm{D}-5}$ & $\begin{array}{l}\text { Rokugatani north } \\
\text { dol.dykes No.2 }\end{array}$ & dyke & T.2m $\times ?$ & 4 & $E-W$ & dolerite \\
\hline$\overline{\mathrm{D}} \overline{-6}$ & $\begin{array}{l}\text { Sugio } \\
\text { dolerite dyke }\end{array}$ & dyke & $0.7 \mathrm{~m} \times 5 \mathrm{~m}$ & 7 & SSE-NNW & dolerite \\
\hline$\overline{D-7}$ & $\begin{array}{l}\text { Maruyama } \\
\text { doferite dykes }\end{array}$ & dyke & $70 \mathrm{~m} \times 270 \mathrm{~m}$ & 4 & S-N & dolerite-gabbro \\
\hline
\end{tabular}

Abbreviation ; chill.-m. dol. : chilled marginal dolerite, g. : gabbro, ol. : olivine, aug. : augite

mentation can not be observed in the dyke rock. The word "complex" is used for the igneous body which is characterized by the presence of various rock species of wide range of composition due to the fractional crystallization. The Murotomisaki gabbroic complex and the Maruyama gabbroic complex are the two cases of such complex in this area. The word "gabbroic body" is used for the igneous intrusive mass which represents the form of stock or pipe. Some of them are irregularly shaped. Comparatively .wide hornfels zone for the small size, which attains to 5 to $0.3 \mathrm{~m}$, is characteristic of the gabbroic rocks.

As it is already described in chapter III, the volcanic rocks in the Shiina Formation are volcanic brrecia, augite basalt, pillow lava and a small amount of pyroclastic rocks. These extrusive rocks are distributed also straightly in a NNE-SSW direction along the east coast of Muroto Peninsula. The narrow igneous zone including the intrusive and extrusive igneous rocks is named "Muroto Peninsula Igneous Zone" in this paper. This igneous zone extends northward to Sakihama (Fig. 1). These igneous rocks are concentrated in five small areas in that igneous zone (Fig. 6). Cape Muroto, Takaoka, Mitaka, Maruyama and
Hioki are the centers of the small areas in the igneous zone. The distribution of these five small areas is closely related to the geological structure as it will be discussed later.

All the volcanic rocks along the coast between Maruyama and Shiina disappear westward and are intertongued with sandstone rich facies. Thus the igneous rocks are concentrated in a narrow zone forming a ridge, a kind of small seamount.

The Maruyama gabbroic complex (G-2) locates stratigraphically and geotectonically just beneath the volcanic rock group of Hioki. A large dyke with branches (D-7) extends from the Maruyama gabbroic complex to Hioki. This dyke is estimated to be a sort of volcanic vent connecting the submarine volcano at Hioki and its magmatic chamber. The chemical composition of augite in the augite basalt at Hioki corresponds to that of augite at the latest differentiation stage in the Maruyama gabbroic complex. This mineralogical result supports the geological implication that the Maruyama gabbroic complex was located just beneath the Hioki volcanic complex, and that the magma, which composed the submarine volcano, was supplied through a vent at Maruyama.

These igneous rocks in the studied area con- 
stitutes a volcano-plutonic complex as a whole, and there is a close correspondence between the extrusive rock and the intrusive rock groups. The depth of the intrusives are stratigraphically estimated to have been $1 \mathrm{~km}$ at the shallowest position and $8 \mathrm{~km}$ at the deepest position from the top of the submarine surface. Reconstructing the three dimensional geological structure at the time of magmatic intrusion, all the igneous rocks in the studied area are deduced to have been supplied by various differentiated magmas from one or two magmatic reservoirs at depth (Fig. 7). Each igneous rock group comes from a branch of that magmatic reservoir or those magmatic reservoirs.

\section{Structural position of the Muroto Peninsula igneous zone}

a) It is very outstanding that small gabbroic intrusive bodies to the north of port Takaoka (G-3 to 7) are found without exception at the place where disturbances of strike and dip are characteristic. The same tendency is recognized at the Relay Station, south of Mt. Odare (R. S. N. H. K. in Fig. 3-b), where the variation of dip and strike is characteristic and a small intrusive dioritic pipe of $3 \mathrm{~m}$ in diameter is found. These disturbances are supposedly due to the emplacement force of the intrusive magma. In contrast, not so remarkable disturbances of dip and strike can be observed in the surroundings of the fractionally crystallized Murotomisaki gabbroic complex $(\mathrm{G}-1)$. This will be explained by the concordant intrusion with a form of sheet. In the case of the Maruyama gabbroic complex $(\mathrm{G}-2)$ and its surrrounding area, it is clearly represented on the lithofacies map (Fig. 3-b) that the magma intruded intraformationally into the space between sandstone lens and slumping bed of mudsone.

b) Outstanding summits of the wavy structures are observed at the east coast near Port Takaoka and Port Mitsu, whereas a small summit is noticed at a point, north of Port Marobae (Fig. 3-b). The comparatively coarse-grained facies is distributed at the both wing sides of the wavy structure, but that facies is missing at the summit. The small intrusives (D-2, G-3, G-2, D-7, in Fig. 3-b) are observed on the position from the summit to the wing along the wavy. structure.

These features demonstrate that the wavy structure was grown in the process of the sedimentation and that this structure was formed by the force which is closely related to the igneous activities. The wavy structure is concluded to be a part of small dome-basin structure, which was formed under the effect of the magmatic uplift movement.

c) As described before, the sedimentary facies in the studied area is composed of sandstone, alternation of sandstone and mudstone, mudstone, and tuffaceous rocks. The general trend of strike of the Sakamoto and the lower Murotsu Formations is NE-SW direction, while that of the upper Murotsu and the Shiina Formations is E-W direction (Fig. 6). This general tendency is well explained by the presence of a nose structure dipping to north, west wing of which can be observed on land. This nose structure could not be preserved perfectly and was partially broken by the Murotsu-Mitsu fault. However, the variation of the thickness of the Sakamoto and the Murotsu Formations c'early indicates the original nose structure in this area.

The total thickness of the sedimentary rocks decreases northeastward, accompanying a remarkable decrease of coarse-grained facies in the south area nearby the boundary between the Murotsu and the Sakamoto Formations. These formations consist of the lower sandstone rich facies and the upper mudstone rich facies, but the coarse-grained facies decreases remarkably toward northeast in each formation (Fig. 3-b).

Therefore, the igneous zone is located on the position, where the total thickness of the formation is the thinnest, and where the coarsegrained facies is lacking. These characteristics of lithofacies demonstrate that the aforesaid anticlinal structure, which is represented as a nose structure at present time, is a synsedimentary structure that has grown gradually during the process of the sedimentation.

Thus the principal structure of the first order including the nose structure and the minor structure of the second order including the wavy structures are attributed to the synsedimentary structure, not to the episedimentary 
structure. And the geological structure is deduced to be closely related to the igneous activities. There was a zone of uplift on the east coast, where the nose structure can be recognized at present. The center of igneous activities was located on this zone of uplift. The principal variation of the lithofacies is attributed to the presence of the zone of uplift.

d) KatTo \& ARITA (1966) estimated the presence of an anticline of SW-NE direction on the place of the Murotomisaki gabbroic complex (G-1) in the south part of Cape Muroto and called it "Murotomisaki anticline". They considered the Murotomisaki gabbroic complex as an intrusive mass intruded vertically along the anticlinal axis. However, one of the writers (YAJIMA, 1972a) studied the fractional crystallization of this complex and demonstrated that the magma of this complex intruded horizontally into the formation almost concordantly as a sheet, although partially discordantly. A continuous transition of rock species in this complex from the chilled marginal dolerite, through picrite gabbro, augite gabbro to ferro gabbro clearly demonstrates the gravitational fractionation of the magma at the horizontal state of intrusion. South side of this complex used to be in the lower position of the gravitationally fractionated sheet, while north side used to be in the upper position as shown in the columnar section 1 of Fig. 4.

Gradings in the sandstone-rich alternation developed along the south or southeast side of the gabbroic complex at the southern end of Cape Muroto give the evidence indicating northward or northwestward normal dipping of the formation. Mode of cross lamination of ripple marks is compatible with the estimation that the north side sedimentary sequence belongs to the upper horizon. The transitional relation of rock facies from sandstone to mudstone in the alternation also supports this conclusion. Gradings of the sandstone in the alternation exposing at the north neighbourhood of the gabbroic complex also indicate the same inclination of the sedimentary sequence, namely, north side belongs to the upper horizon. Sedimentary structure of small scale disturbs general trend in some parts, however, the principal tendency is preserved as a whole.
Therefore, it is evident that the Murotomisaki gabbroic complex is not a mass vertically intruded into an anticlinal axis but a horizontally intruded sheet in the Sakamoto Formation. The difference of lithofacies of the both sides of the anticlinal axis at the extremity of Cape Muroto can be well explained by the presence of a fault parallel to that axis. Fault planes of this type are observed at the contact between the pebbly mudstone bed and the mudstone rich alternation at the extremity of the Cape.

On the basis of the above discussed geological features following conclusions will be obtained. First, the principal epoch of the magmatic intrusions in the studied area was at the Shiina Stage. Second, at the time of the magmatic intrusion, namely at the Shiina Stage, the Sakamoto and the Murotsu Formations were not yet so much affected by the geotectonical movement, which caused afterward the steep tilting of the Sakamoto and the Murotsu Formations. Third, an anticlinal structure with small dome-basin structures was formed during the process of the sedimentation. The principal features of the geological structure are illustrated on Fig. 7.

\section{Role of the Muroto peninsula igne-} ous zone on the tectonic movement

Because the thickness of clastic rocks is closely related to the distribution of the igneous zone in this area, it is estimated that the local active center of this igneous zone was a small seamount. There was a small seamount chain of N-S direction bounded by the two sedimentary basins located on the east and the west sides of the igneous zone. That zone itself was an uplifting zone between these two sedimentary basins and the igneous activities were closely related to this uplift movement. These two basins may have been continuous to each other. Thus, it might be suggested that there was a small zone of uplift in the Shimanto geosynclinal terrain in N-S direction.

Observing the geological features in detail, the slope of the sedimentary margin represents wavy structures, a kind of undulation. Reconstructing the geological structure three dimensionally, this structure is demonstrated to be consisting of a small domes with inclined 
distribution. Many small faults are found on the position of wing or between summit and wing of this wavy structures and small intrusives are found on this position.

When the sedimentary beds upheave like a dome on anticline, many normal faults develop on the dome or along the anticline (KoDAMA et al., 1974). So that the igneous activities are concentrated along those faults, and many dykes and sheets of igneous rocks are developed there. This might be the case of the Muroto Peninsula igneous zone. The formation of that structure is supposed to be due to the uplift movement of the magma at depth.

\section{References}

Kлtто, J., 1960: Some Problematica from the so-called Unknown Mesozoic Strata of the southern part of Shikoku, Japan. Sci. Rept. Tohoku Univ. [2], 4, 323-334.

, 1969: Geology of Kochi Prefecture. Library of Kochi city, Kochi, 316p.

and Arita, M., 1966: Geology of the

Muroto Peninsula, Shikoku, Japan (1). Sci. Rept.

Kochi Univ., 15, 59-63.
Kodama, K., Suzuki Y., Ogawa, G. and Maruta, Y., 1974: On the internal structure of boxshaped folds. Rept. Geol. Survey Japan, 250--2, $117-143$.

Suzuki, T., 1930: Geological sheet map "Muroto", scale $1 / 75,000$, and its explanatory text. Geol. Surv. Japan.

YaJima, T., 1969: Some aspects of fractional crystallization of basaltic magmas. Mem. Fac. Edu. Saitama Univ., 18, 127-141. , 1972a: Petrology of the Murotomisaki gabbroic complex. Jour. Japan. Assoc. Miner. Petrol. Econ. Geol., 67, 218-241.

, 1972b: Petrochemistry of the Murotomisaki gabbroic complex. Ibid., 67, 247-261.

Yoder H. S. Jr. and Tilley G. E., 1962: Origin of basalt magmas, an experimental study of natural and synthetic rock systems. Jour. Petrol. 3, 342-532.

Yoshizawa, H., 1953: On the gabbro of the Cape of Muroto, Shikoku Island, Japan (Part 1). Mem. Coll. Sci., Kyoto Univ., 20, 271-284.

1954: On the gabbro of the Gape of Muroto, Shikoku Island, Japan (Part 2). Ibid., 21, $193-212$. 


\title{
構造運動における火成活動の役割特に窒戸半島火成活動帯について
}

\author{
矢島 敏彦・梶間 幹雄・長沼 幸男
}

(要 旨)

室戸半島南端部の室戸半島層群は, 下部より坂本層·室 津層・椎名層よりなる.坄本層・室津層分布地域では主 として北側定上位とする急傾斜の単斜構造を示している が，東海岸に沿って波長の短い波曲構造が見られる。層 厚は西海岸側で厚く，東海岸側て薄い。両層は全体之己 て東海岸に沿った南北の軸をるつノーズ構造の西翼を代 垶するものと考元られる。椎名層分布地域では主に東西 性の軸をるつ䐴曲構造が顕著になってくる．東海岸に沿 ってほほぼ南北方向に多数の小はん机い岩体，粗粒玄武岩 体があらたに発見され，室戸䛅はえれい岩体より丸山の は九れい岩体，日沖の梡状溶岩に至る区間に，極めて多 数の小火成岩体がせまい带状の地域に分布することがわ かった. 本研究に扔いて筆者らはこれ室戸半島火成活 動带と呼えだ.この火成活動帯は更に北方佐喜浜方面に までその延長が認められる. この火成活動带において， 火成岩体は主として波曲構造の峰から翼部にかかる部位 に貫入している，従ってノーズ構造を含さ第一級の構造 も, 波曲構造客含第二級の構造も共に堆積時から形成 されはじめていた構造であり，いずれも火成活動に関連 して形成されたことがわかる．この火成活動带の活動時 の形態を三次元的に復元してみると，この地域では小ド 一ム状構造が数珠の上うに連続しており，てれが全体と

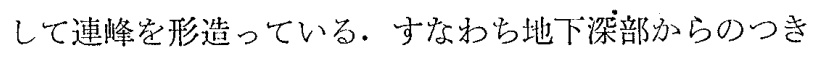
あげ運動が，小ドームの連珠状配列を形成させ，乙の時 形成された小断裂群に沿ってマグマの貫入が行われた。 この際の室户半島層群の基盤は凹凸の方海領状の形態 をして叔り, 東海岸側に沿って基盤が浅くなったあのと 考光られる.これはマグマの上昇運動に関連したもので あるう。
地

\begin{tabular}{|c|c|}
\hline Akabarabae & 赫バラバエ \\
\hline Asuka & 飛鳥 \\
\hline Bishagobae & 昆沙姑㳻 \\
\hline Cape Muroto & 空戸归 \\
\hline Hioki & 日沖 \\
\hline Kobishagobae & 小昆沙姑婆 \\
\hline Kurato & 蔵戸 \\
\hline Maruyama & 丸山 \\
\hline Mt. Odare & 尾乗山 \\
\hline Mt. Shijuji & 四十寺山 \\
\hline Murotsu & 室津 \\
\hline Nabae & 菜生 \\
\hline Narashi & 奈良師 \\
\hline Ohguibae & オオグイバエ \\
\hline Port Takaoka & 高阔港 \\
\hline Port Marobae & マロバエ港 \\
\hline Port Mitsu & 三津港 \\
\hline Rokugatani & 突ケ谷 \\
\hline Ryoke & 領家 \\
\hline Sakamoto & 坂本 \\
\hline Sakihama & 佳喜浜 \\
\hline Shiina & 椎名 \\
\hline Sugio shrine & 杉尾神社 \\
\hline Takaiwa & 高紧 \\
\hline Teonobac & 手谷粱 \\
\hline Tsuro & 津呂 \\
\hline Yamada & 山田 \\
\hline Yamada's Residence & 山世馎 \\
\hline
\end{tabular}

